Volume 2, Issue 2, October 2021, p. 39-44

P-ISSN 2745-6498, E-ISSN 2745-8008

\title{
Stadium, Diagnosis, dan Tatalaksana Penyakit Alzheimer
}

\author{
Aditya Gloria Monalisa Sianturi
}

Fakultas Kedokteran Universitas Lampung

\section{ARTICLE INFO}

Article history:

Received 21 April 2021

Accepted 21 August 2021

Published 25 October 2021

Keyword:

Alzheimer's disease

Alzheimer's stage

Alzheimer's diagnose

Alzheimer's treatment

\begin{abstract}
A B S T R A C T
Dementia is a general term for loss of memory that can occur along with behavioral or psychological symptoms in patients. The first cause of dementia patients is Alzheimer's disease. Alzheimer's disease is a brain degenerative disease and the most common cause of dementia. In Alzheimer's disease, there are three development stages, which is stage 1, stage 2, and stage 3 with different clinical symptoms at each stage. There are several clinical criteria for establishing a definitive diagnosis of Alzheimer's disease and also support examinations have to be carried out. Until now, Alzheimer's treatment has not been cured. Giving some pharmacotherapy only to reduce the progression of Alzheimer's disease.
\end{abstract}

This open access article is under the CC-BY-SA license.

\begin{abstract}
Kata kunci:
Penyakit Alzheimer

Stadium alzheimer

Diagnosis alzheimer

Tatalaksana alzheimer

*) corresponding author

Fakultas Kedokteran Universitas Lampung Jl. Prof. Dr. Ir. Sumantri Brojonegoro No. 1 Gedong Meneng, Kec. Rajabasa

Kota Bandarlampung, Indonesia,

Telp. 081277528471

Email: monalisasianturi24@gmail.com

A B S T R A K

Demensia merupakan hilangnya ingatan yang bisa timbul bersama dengan gejala gangguan perilaku maupun psikologis pada seseorang. Penyebab pertama penderita demensia adalah penyakit Alzheimer. Penyakit Alzheimer adalah penyakit degeneratif otak dan penyebab paling umum dari demensia. Pada penyakit Alzheimer terdapat beberapa stadium perkembangan penyakit Alzheimer yaitu stadium 1, stadium 2, dan stadium 3 dengan gejala klinik yang berbeda di setiap stadium. Terdapat beberapa kriteria klinis dalam penegakan diagnosis definitif penyakit Alzheimer serta harus dilakukan pemeriksaan penunjang. Pada tatalaksana penyakit Alzheimer hingga saat ini memang belum dapat disembuhkan, Pemberian obat-obatan hanya untuk mengurangi progresifitas penyakit Alzheimer.
\end{abstract}

DOI: $10.47679 /$ makein.202132

\section{PENDAHULUAN}

Demensia adalah hilangnya fungsi kognitif secara muldimensional dan terus-menerus, disebabkan oleh kerusakan organik sistem saraf pusat, tidak disertai oleh penurunan kesadaran akut seperti yang terjadi pada delirium. Jenis-jenis demensia yaitu demensia Alzheimer, demensia vascular, demensia karena kondisi medik umum lainnya. Penyakit Alzheimer dapat terjadi pada setiap dekade dewasa, tetapi penyakit ini merupakan penyebab utama demensia pada lanjut usia (Bahan Ajar 1 Penyakit Alzheimer, 2013).

Penyakit Alzheimer adalah penyakit degeneratif otak dan penyebab paling umum dari demensia. Hal ini ditandai dengan penurunan memori, bahasa, pemecahan masalah dan keterampilan kognitif lainnya yang mempengaruhi kemampuan seseorang untuk melakukan kegiatan seharihari. Penurunan ini terjadi karena sel-sel saraf (neuron) di bagian otak yang terlibat dalam fungsi kognitif telah rusak dan tidak lagi berfungsi normal (Alzheimer's Association, 2017).

Pada penyakit Alzheimer, kerusakan saraf akhirnya mempengaruhi bagian otak yang memungkinkan seseorang untuk melaksanakan fungsi tubuh dasar seperti berjalan dan menelan. Pada akhirnya, penderita dapat mengalami kematian setelah beberapa tahun karena kemampuan motoriknya sudah tidak berfungsi (Alzheimer's Association, 2017). 
Alzheimer diduga terjadi karena penumpukan protein beta-amyloid yang menyebabkan plak pada jaringan otak. Secara normal, beta-amyloid tidak akan membentuk plak yang dapat menyebabkan gangguan sistem kerja saraf pada otak. Namun, karena terjadi misfolding protein, plak dapat menstimulasi kematian sel saraf (Pattni, 2013).

\section{METODE}

Telah dijelaskan bahwa penyakit Alzheimer merupakan salah satu jenis demensia yang terbanyak pada orang dewasa. Demensia sudah sering dikenal dengan menggunakan kriteria DSM IV (Diagnostic and Statistical Mnual of Mental Disorders, fourth edition). Menegakkan diagnosis penyakit Alzheimer dengan menggunakan kriteria oleh the National Institute of Neurological and Communicative Disorders and Stroke (NINCDS) dan the Alzheimer's Disease and Related Disorders Association (ADRDA) dengan menggunakan klasifikasi definitive (diagnosis klinis dengan gambaran histologi), probable (sindrom klinik tipikal tanpa gambaran histologi) dan possible (gambaran klinis atipikal tetapi tidak ada diagnosis alternatif dan tidak ada gambaran histologi) (Bahan Ajar 1 Penyakit Alzheimer, 2013).

Dalam penegakan diagnosis penyakit Alzheimer, juga dilakukan pemeriksaan penunjang neuropatologi, neuropsikologik, CT (Computerised Tomography) Scan/ MRI (Magnetic Resonance Imaging), EEG (Elektroensefalogram), PET (Position Emission Tomography), SPECT (Single Photon Emission Computed Tomography) (Bahan Ajar 1 Penyakit Alzheimer, 2013).

\section{HASIL DAN DISKUSI}

Ada 3 (tiga) stadium Alzheimer Demensia (AD), yaitu (1). Stadium amnesia di mana terdapat diskalkuli dan apraksia, (2). Stadium confusion di mana terjadi afasia, disorientasi waktu, tempat, bingung, perilaku abnormal dan adanya episode psikotik. Stadium akhir adalah (3). Stadium demensia dimana terdapat gangguan kognisi berat, inkontinensia, kelainan neurologi berupa kejang, refleks patologik-primitif sehingga ia hanya tidur saja. Berikut uraian tiap stadium perkembangan penyakit Alzheimer:

1. Stadium 1 (lama penyakit 1-3 tahun)

- Ingatan: new learning defective, remote recall mildly impaired.

- Kemampuan visuospasial: topographic disorientation, poor complex contructions.

- Bahasa: poor wordlist generation, anomia.

- Personalitas: indifference, occasional irritability.

2. Stadium 2 (lama penyakit 3-10 tahun)

- Ingatan: hanya mengingat hal yang sudah diulang beberapa kali.

- Kemampuan visuospasial: spatial disorientation.

- Bahasa: fluent aphasia.

- Personalitas: indifference, irritability.

3. Stadium 3 (lama penyakit 8-12 tahun)

Hanya tidur dan tidak mengingat apa-apa lagi selain kejadian masa lalu. (Alzheimer's Association, 2018).

Kriteria untuk diagnosis klinis untuk probable penyakit Alzheimer mencakup:
- Demensia yang ditegakkan oleh pemeriksaan klinis dan tercatat dengan pemeriksaan the mini-mental test, Blessed Dementia Scale, atau pemeriksaan sejenis, dan dikonfirmasi oleh tes neuropsikologis.

- Defisit pada dua atau lebih area kognitif.

- Tidak ada gangguan kesadaran.

- Awitan antara umur 40 dan 90, umumnya setelah umur 65 tahun.

- Tidak adanya kelainan sistemik atau penyakit otak lain yang dapat menyebabkan defisit progresif pada memori dan kognitif. (Bahan Ajar 1 Penyakit Alzheimer, 2013).

Diagnosis probable penyakit Alzheimer didukung oleh:

- Penurunan progresif fungsi kognitif spesifik seperti afasia, apraksia, dan agnosia.

- Gangguan aktivitas hidup sehari-hari dan perubahan pola perilaku.

- Riwayat keluarga dengan gangguan yang sama, terutama bila sudah dikonfirmasi secara neuropatologi.

- Hasil laboratorium yang menunjukkan pungsi lumbal yang normal yang dievaluasi dengan teknik standar.

- Pola normal atau perubahan yang nonspesifik pada EEG, seperti peningkatan aktivitas slow-wave.

- Bukti adanya atrofi otak pada pemeriksaan CT yang progresif dan terdokumentasi oleh pemeriksaan serial. (Bahan Ajar 1 Penyakit Alzheimer, 2013).

Gambaran klinis lain yang konsisten dengan diagnosis probable penyakit Alzheimer, setelah mengeksklusi penyebab demensia selain penyakit Alzheimer:

- Perjalanan penyakit yang progresif namun lambat (plateau).

- Gejala-gejala yang berhubungan seperti depresi, insomnia, inkontinensia, delusi, halusinasi, verbal katastrofik, emosional, gangguan seksual, dan penurunan berat badan.

- Abnormalitas neurologis pada beberapa pasien, terutama pada penyakit tahap lanjut, seperti peningkatan tonus otot, mioklonus, dan gangguan melangkah.

- Kejang pada penyakit yang lanjut.

- Pemeriksaan CT normal untuk usianya. (Bahan Ajar 1 Penyakit Alzheimer, 2013).

Gambaran yang membuat diagnosis probable penyakit Alzheimer menjadi tidak cocok adalah:

- Onset yang mendadak dan apolectic.

- Terdapat defisit neurologis fokal seperti hemiparesis, gangguan sensorik, defisit lapang pandang, dan inkoordinasi pada tahap awal penyakit.

- Kejang atau gangguan melangkah pada saat awitan atau tahap awal perjalanan penyakit. (Bahan Ajar 1 Penyakit Alzheimer, 2013).

Kriteria diagnosis possible penyakit Alzheimer mencakup:

- Dibuat berdasarkan adanya sindrom demensianya, tanpa adanya gangguan neurologis psikiatrik, atau sistemik lain yang dapat menyebabkan demensia, dan adanya variasi pada awitan, gejala klinis, atau perjalanan penyakit.

- Dibuat berdasarkan adanya gangguan otak atau sistemik sekunder yang cukup untuk menyebabkan demensia, namun penyebab primernya bukan merupakan penyebab demensia. (Bahan Ajar 1 Penyakit Alzheimer, 2013).

Kriteria untuk diagnosis definitive penyakit Alzheimer adalah:

- Kriteria klinik untuk probable penyakit Alzheimer. 
- Bukti histopatologi yang didapat dari biopsi atau autopsi. (Bahan Ajar 1 Penyakit Alzheimer, 2013).

Klasifikasi penyakit Alzheimer untuk tujuan penelitian dilakukan bila terdapat gambaran khusus yang mungkin merupakan subtipe penyakit Alzheimer, seperti:

- Banyak anggota keluarga yang mengalami hal yang sama.

- Awitan sebelum usia 65 tahun.

- Adanya trisomi-21.

- Terjadi bersamaan dengan kondisi lain yang relevan seperti penyakit Parkinson. (Bahan Ajar 1 Penyakit Alzheimer, 2013).

Dalam penegakan diagnosis definitif penyakit Alzheimer juga dilakukan pemeriksaan penunjang. Pemeriksaan penunjang yang dapat dilakukan antara lain:

1. Neuropatologi

Diagnosis definitif tidak dapat ditegakkan tanpa adanya konfirmasi neuropatologi. Secara umum didapatkan atrofi yang bilateral, simetris, sering kali berat otaknya berkisar 100 gram (850-1250 gram). Beberapa penelitian mengungkapkan atropi lebih menonjol pada lobus temproparietal, anterior frontal, sedangkan korteks oksipital, korteks motorik primer, sistem somatosensorik tetap utuh (Perl, 2010). Kelainankelainan neuropatologi pada penyakit Alzheimer terdiri dari:

\section{- Neurofibrillary Tangles (NFT)}

Merupakan sitoplasma neuronal yang terbuat dari filament-filamen abnormal yang berisi protein neurofilamen, ubiquine, epitoque. NFT ini juga terdapat pada neokorteks, hipokampus, amigdala, substansia alba, lokus seruleus, dorsal raphe dari inti batang otak. NFT selain didapatkan pada penyakit Alzheimer, juga ditemukan pada otak manula, down syndrome, Parkinson, SSPE, sindroma ekstrapiramidal, supranuklear palsy. Densitas NFT berkolerasi dengan beratnya demensia.

\section{- Senile Plaque(SP)}

Merupakan struktur kompleks yang terjadi akibat degenerasi nerve ending yang berisi filament-filamen abnormal, serta amyloid ekstraseluler, astrosit, mikroglia. Protein precursor amyloid yang terdapat pada SP sangat berhubungan dengan kromosom 21. Senile plaque ini terutama terdapat pada neokorteks, amygdala, hipokampus, korteks piriformis, dan sedikit didapatkan pada korteks motorik primer, korteks somatosensorik, korteks visual, dan auditorik. Senile plaque ini juga terdapat pada jaringan perifer. Kedua gambaran histopatologi (NFT dan senile plaque) merupakan gambaran karakteristik untuk penderita penyakit Alzheimer.

- Degenerasineuron

Pada pemeriksaan mikroskopik perubahan dan kematian neuron pada penyakit Alzheimer sangat selektif. Kematian neuron pada neokorteks terutama didapatkan pada neuron pyramidal lobus temporal dan frontalis. Juga ditemukan pada hipokampus, amigdala, nukleus batang otak termasuk lobus seruleus, raphe nukleus, dan substansia nigra. Kematian sel neuron kolinergik terutama pada lokus seruleus serta sel serotogenik pada nukleus raphe dorsalis, nukleus tegmentum dorsalis. Telah ditemukan faktor pertembuhan saraf pada neuron kolinergik yang berdegenerasi pada lesi eksperimental binatang dan ini merupakan harapan dalam pengobatan penyakit Alzheimer.

\section{- Perubahan vakuoler}

Merupakan suatu neuronal sitoplasma yang berbentuk oval dan dapat menggeser nukleus. Jumlah vakuoler ini berhubungan secara bermakna dengan jumlah NFT dan SP, perubahan ini sering didapatkan pada korteks frontalis, parietal, oksipital, hipokampus, serebelum dan batang otak.

\section{- Lewy body}

Merupakan bagian sitoplasma intraneuronal yang banyak terdapat pada enterhinal, gyrus cingulate, korteks insula, dan amygdala. Sejumlah kecil pada korteks frontalis, temporal, parietalis, oksipital. Lewy body kortikal ini sama dengan imunoreaktivitas yang terjadi pada lewy body batang otak pada gambaran histopatologi penyakit Parkinson. Lewy body merupakan varian dari penyakit Alzheimer. (Bahan Ajar 1 Penyakit Alzheimer, 2013).

2. Pemeriksaan neuropsikologik

Penyakit Alzheimer selalu menimbulkan gejala demensia. Fungsi pemeriksaan neuropsikologik ini untuk menentukan ada atau tidak adanya gangguan fungsi kognitif umum dan mengetahui secara rinci pola defisit yang terjadi. Tes psikologis ini juga bertujuan untuk menilai fungsi yang ditampilkan oleh beberapa bagian otak yang berbeda-beda seperti gangguan memori, kehilangan ekspresi, kalkulasi, perhatian, dan pengertian berbahasa. Evaluasi neuropsikologis yang sistemik mempunyai fungsi diagnostik yang penting karena:

a. Adanya defisit kognisi yang berhubungan dengan demensia awal yang dapat diketahui bila terjadi perubahan ringan yang terjadi akibat penuaan yang normal.

b. Pemeriksaan neuropsikologik secara komprehensif memungkinkan untuk membedakan kelainan kognitif pada global demensia dengan defisit selektif yang diakibatkan oleh disfungsi fokal, faktor metabolik, dan gangguan psikiatri.

c. Mengidentifikasi gambaran kelainan neuropsikologik yang diakibatkan oleh demensia karena berbagai penyebab.

The Consortium to establish a Registry for Alzheimer Disease (CERALD) menyajikan suatu prosedur penilaian neuropsikologis dengan mempergunakan alat yang bermanifestasi gangguan fungsi kognitig, dimana pemeriksaannya terdiri dari:

- Verbal fluency animal category.

- Modified boston naming test.

- Mini mental state.

- Word list memory.

- Constructional praxis.

- Word list recall.

- Word list recognition.

Tes ini memakan waktu 30-40 menit dan $<20-30$ menit untuk kontrol.

\section{CT Scan dan MRI}

Merupakan metode non invasif yang beresolusi tinggi untuk melihat kuantifikasi perubahan volume jaringan otak pada penderita Alzheimer antemortem. Pemeriksaan ini berperan dalam menyingkirkan kemungkinan adanya penyebab demensia lainnya selain Alzheimer seperti multi infark dan tumor serebri. Atropi kortikal menyeluruh dan pembesaran ventrikel keduanya merupakan gambaran marker dominan yang sangat spesifik pada penyakit ini. Tetapi gambaran ini juga didapatkan pada demensia lainnya seperti multi infark, 
Parkinson, binswanger sehingga kita sukar untuk membedakan dengan penyakit Alzheimer.

Penipisan substansia alba serebri dan pembesaran ventrikel berkorelasi dengan beratnya gejala klinik dan hasil pemeriksaan status mini mental. Pada MRI ditemukan peningkatan intensitas pada daerah kortikal dan periventrikuler (capping anterior horn pada ventrikel lateral). Capping ini merupakan predileksi untuk demensia awal. Selain didapatkan kelainan di kortikal, gambaran atropi juga terlihat pada daerah subkortikal seperti adanya atropi hipokampus, amygdala, serta pembesaran sistena basalis dan fisura sylvii. MRI lebih sensitif untuk membedakan demensia dari penyakit Alzheimer dengan penyebab lain, dengan memperhatikan ukuran (atropi) dari hipokampus.

4. EEG (elektroensefalogram)

Berguna untuk mengidentifikasi aktivitas bangkitan yang subklinis. Sedangkan pada penyakit Alzheimer didapatkan perubahan gelombang lambat pada lobus frontalis yang non spesifik.

5. PET (Positron Emission Tomography)

Pada penderita Alzheimer, hasil PET ditemukan penurunan aliran darah, metabolisme $\mathrm{O}_{2}$, dan glukosa di daerah serebral. Uptake I. 123 sangat menurun pada regional parietal, hasil ini sangat berkolerasi dengan kelainan fungsi kognisi dan selalu sesuai dengan hasil observasi penelitian neuropatologi.

6. SPECT (Single Photon Emission Computed Tomography). Aktivitas I. 123 terendah pada region parietal penderita Alzheimer. Kelainan ini berkorelasi dengan tingkat kerusakan fungsional dan defisit kognitif. Kedua pemeriksaan ini (SPECT dan PET) tidak digunakan secara rutin. (Bahan Ajar 1 Penyakit Alzheimer, 2013).

Penyakit Alzheimer hingga saat ini memang belum dapat disembuhkan, selain itu belum adanya obat-obatan yang memiliki keefektivan hasil bagi pasien Alzheimer. Obatobatan tersebut hanya mengurangi progresifitas penyakit Alzheimer sehingga hanya memberikan rasa tenang bagi pasien, sehingga mengurangi perubahan emosi dan perilakunya dalam kehidupan sehari-hari (Alzheimer's Association, 2021).

Terapi yang dapat diberikan untuk pasien Alzheimer yaitu terapi farmakologis dengan penggunaan obat-obatan dan terapi non farmakologis. Terapi farmakologis pada pasien Alzheimer difokuskan pada tiga domain: mempertahankan fungsi kognitif, perilaku dan gejala kejiwaan. Sedangkan terapi non farmakologi dilakukan untuk mempertahankan fungsi kognitif yang masih ada dengan berbagai macam program kegiatan yang dapat diberikan, antara lain terapi relaksasi dan latihan fisik untuk menyehatkan kerja otak, serta senam otak (Alzheimer's Association, 2021).

\section{Terapi non-farmakologis}

Merupakan cara terapi menggunakan pendekatan selain obat-obatan. Terapi non-farmakologis sering digunakan dengan tujuan mempertahankan atau meningkatkan fungsi kognitif, kemampuan untuk melakukan aktivitas sehari-hari, atau kualitas hidup secara keseluruhan. Mereka juga dapat digunakan dengan tujuan mengurangi gejala perilaku seperti depresi, apatis, mengembara, gangguan tidur. Terapi non-farmakologis diperlukan untuk lebih mengevaluasi efektivitas mereka dalam kehidupan sehari-hari. Prinsipprinsip dasar dalam pengobatan pasien dengan Alzheimer meliputi kegiatan yang mencakup mengenai kegiatan dan lingkungan pasien rehabilitasi. Lingkungan yang dimaksud adalah lingkungan keluarga dan masyarakat serta lingkungan alam. Dalam konteks kegiatan pada pasien meliputi kegiatan kreatif seperti olahraga, kegiatan keseharian secara konsisten. Dalam konteks lingkungan yang mencakup keluarga dan masyarakat adalah menggunakan pendekatan halus pada pasien, berempati pada pasien, serta dalam konteks lingkungan alam adalah memberikan lingkungan yang aman dan nyaman (Pedoman Praktik Klinik Diagnosis dan Penatalaksanaan Demensia, 2015).

\section{Terapi farmakologis}

Belum ada pengobatan spesifik untuk penyakit Alzheimer. Pengobatan secara simtomatik, sosial, terapi psikiatri dan dukungan keluarga menjadi pilihan terapi yang digunakan saat ini. Acetylcholinesterase inhibitors atau $N$-methyl-D-aspartate (NMDA) inhibitor (Memantin) dapat meningkatkan fungsi kognitif pada penyakit Alzheimer stadium awal (Yosenia, 2018).

\section{1) Cholinesterase inhibitor}

Beberapa tahun terakhir ini, banyak peneliti menggunakan inhibitor untuk pengobatan simptomatik penyakit Alzheimer, dimana penderita Alzheimer didapatkan penurunan kadar asetilkolin. Cholinesterase inhibitor telah diakui untuk pengobatan penyakit Alzheimer ringan sampai sedang yang juga dijadikan standar perawatan untuk pasien dengan penyakit Alzheimer. Kerja farmakologis dari donepezil, rivastigmine, dan galantamine adalah menghambat cholinesterase, dengan menghasilkan peningkatan kadar asetilkolin di otak. Untuk mencegah penurunan kadar asetilkolin dapat digunakan anti kolinesterase. Pemberian obat ini dikatakan dapat memperbaiki memori dan apraksia selama pemberian berlangsung. 4 jenis cholinesterase inhibitor yang paling sering digunakan adalah:

a. Donepezil (merk dagang ARICEPT $^{\circledR}$ ) disetujui untuk pengobatan semua tahap penyakit Alzheimer.

b. Galantamine (merk dagang RAZADYNE ${ }^{\circledR}$ ) disetujui untuk tahap ringan sampai sedang.

c. Rivastigmine (merk dagang EXELON ${ }^{\circledR}$ ) untuk tahap ringan sampai sedang.

d. Tacrine (merk dagang COGNEX ${ }^{\circledR}$ ) merupakan cholinesterase inhibitor pertama yang disetujui untuk digunakan sejak tahun 1993, namun sudah jarang digunakan saat ini karena faktor resiko efek sampingnya, salah satunya adalah kerusakan hati.

Pemberian dosis dari ketiga cholinesterase inhibitor yang umum digunakan adalah sebagai berikut:

a. Donepezil dimulai dengan dosis $5 \mathrm{mg}$ per hari, kemudian dosis ditingkatkan menjadi $10 \mathrm{mg}$ per hari setelah 1 bulan.

b. Dosis rivastigmine ditingkatkan dari $1,5 \mathrm{mg}$ dua kali sehari sampai $3 \mathrm{mg}$ dua kali sehari, kemudian menjadi 4,5 mg dua kali sehari, dan untuk maksimal dosis $6 \mathrm{mg}$ dua kali sehari.

c. Galantamine dimulai dengan dosis $4 \mathrm{mg}$ dua kali sehari. Pertama-tama, dosis ditingkatkan menjadi $8 \mathrm{mg}$ dua kali sehari dan akhirnya sampai $12 \mathrm{mg}$ dua kali sehari. Seperti rivastigmine, waktu yang 
lebih lama antara peningkatan dosis berhubungan dengan penurunan efek samping.

Pengobatan sehari-hari dengan donepezil memberikan hasil yang efektif dalam kisaran dosis 5 sampai 10 mg; Rivastigmine, dalam kisaran 6 sampai $12 \mathrm{mg}$; serta galantamine, dalam kisaran dari 16 sampai $24 \mathrm{mg}$. (Bahan Ajar 1 Penyakit Alzheimer, 2013).

\section{2) Memantine}

Memantine merupakan obat yang telah diakui oleh Food and Drug Administration (FDA) untuk pengobatan penyakit Alzheimer sedang sampai berat. Dosis awal untuk penggunaan memantine adalah 5 mg per hari, kemudian dosis ditingkatkan berdasarkan penelitian, hingga $10 \mathrm{mg}$ dua kali sehari. Memantine tampaknya bekerja dengan cara memblok saluran $N$-methyl-D-aspartate (NMDA) yang berlebihan. Memantine yang dikombinasikan dengan cholinesterase inhibitor maupun yang tidak, tampaknya dapat memperlambat kerusakan kognitif pada pasien dengan penyakit Alzheimer yang moderat (Bahan Ajar 1 Penyakit Alzheimer, 2013).

\section{3) Thiamin}

Penelitian telah membuktikan bahwa pada penderita Alzheimer didapatkan penurunan thiamin pyrophosphatase dependent enzyme yaitu 2 ketoglutarate $(75 \%)$ dan transketolase $(45 \%)$, hal ini disebabkan kerusakan neuronal pada nukleus basalis. Pemberian thiamin hydrochloride dengan dosis 3 gram per hari selama 3 bulan per oral, menunjukkan perbaikan bermakna terhadap fungsi kognitif dibandingkan placebo selama periode yang sama (Bahan Ajar 1 Penyakit Alzheimer, 2013).

4) Haloperiodol

Pada penderita Alzheimer, sering kali terhadi gangguan psikosis (delusi, halusinasi) dan tingkah laku. Pemberian oral haloperiodol $1-5 \mathrm{mg}$ per hari selama 4 minggu akan memperbaiki gejala tersebut. Bila penderita Alzheimer menderita depresi sebaiknya diberikan trisiklik anti depresan (Amityptiline 25-100 mg/ hari) (Bahan Ajar 1 Penyakit Alzheimer, 2013).

5) Acetyl L-Carnitine (ALC)

Mengapa suatu substrat endogen yang disintesis di dalam mitokondria dengan bantuan enzim ALC transferase. Penelitian ini menunjukkan bahwa ALC dapat meningkatkan aktivitas asetilkolinesterase, kolin asetiltransferase. Pada pemberian dosis 1-2 gram per hari secara per oral selama 1 tahun dalam pengobatan, disimpulkan bahwa dapat memperbaiki atau menghambat progresifitas kerusakan fungsi kognitif (Nisa \& Lisiswanti, 2016).

6) Antioksidan

Pada pasien dengan penyakit Alzheimer sedang sampai berat, penggunaan antioksidan selegiline, $\alpha-$ tokoferol (vitamin E), atau keduanya, memperlambat proses kematian. Karena vitamin E memiliki potensi yang rendah untuk toksisitas dari selegiline, dan juga lebih murah, dosis yang digunakan dalam penelitian untuk diberikan kepada pasien AD adalah $1000 \mathrm{IU}$ dua kali sehari. Namun, efek yang menguntungkan dari vitamin E tetap kontroversial. dan sebagian peneliti tidak lagi memberikan dalam dosis tinggi karena ternyata memiliki potensi dalam menimbulkan komplikasi kardiovaskular.

\section{KESIMPULAN DAN REKOMENDASI}

Demensia merupakan hilangnya fungsi kognitif secara multidimensional dan terus-menerus, disebabkan oleh kerusakan organik sistem saraf pusat, tidak disertai oleh penurunan kesadaran akut seperti yang terjadi pada delirium. Penyakit Alzeimer merupakan salah satu penyebab paling umum dari demensia. Penyakit Alzheimer ditandai dengan penurunan memori, bahasa, pemecahan masalah dan keterampilan kognitif lainnya yang mempengaruhi kemampuan seseorang untuk melakukan kegiatan seharihari. Penyakit Alzheimer disebabkan oleh penumpukan protein beta-amyloid yang memnyebabkan plak pada jaringan otak yang pada akhirnya mempengaruhi sistem saraf pada pasien tersebut. Perkembangan penyakit Alzheimer terbagi menjadi 3 stadium. Yang pertama, stadium 1 atau stadium amnesia di mana terdapat diskalkuli dan apraksia. Stadium 2 atau stadium confusion di mana terjadi afasia, diorientasi waktu, tempat, bingung, perilaku abnormal dan adanya episode psikotik. Dan stadium3 atau stadium demensia di mana terdaoat gangguan kognisi berat, inkontinensia, kelainan neurologi berupa kejang, refleks patologik-primitif sehingga ia hanya tidur saja. Dalam penegakan diagnosis penyakit Alzheimer diperlukan beberapa pemeriksaan menurut kriteria oleh NINCDS dan ADRDA dengan klasifikasi diagnosis definitif, probable, dan possible. Dalam penegakan diagnosis definitif penyakit Alzheimer juga perlu dilakukan pemeriksaan penunjang neuropatologi, neuropsikologik, CT scan/ MRI, EEG, PET, SPECT. Untuk terapi pengobatan penyakit Alzheimer terbagi atas terapi non-farmakologis, seperti kegiatan kreatif olahraga, kegiatan keseharian secara konsisten, menggunakan pendekatan halus kepada pasien, berempati pada pasien, serta memberi lingkungan yang aman dan nyaman bagi pasien. Sedangkan untuk terapi farmakologis hingga saat ini belum ada pengobatan spesifik untuk penyakit Alzheimer. Pengobatan secara simptomatik, sosial, terapi psikiatri dan dukungan keluarga menjadi pilihan terapi yang digunakan saat ini. Pengobatan sehari-hari dengan donepezil memberikan hasil yang efektif dalam kisaran dosis 5-10 mg; Rivastigmine dalam kisaran 6-12 mg' serta galantamine dalam ksiaran 16-24 mg. Pemberian obatobatan hanya untuk mengurangi progresifitas penyakit Alzheimer serta memberikan rasa aman kepada pasien dan keluarga.

Setelah disimpulkan, maka peneliti memberikan beberapa saran untuk peneliti selanjutnya. Diharapkan peneliti selanjutnya dapat mengembangkan tinjauan pustaka tentang penyakit Alzheimer ini seperti upaya-upaya pencegahan, tatalaksana terbaru dan paling efektif untuk pasien penyakit Alzheimer.

Dengan segala keterbatasan, peneliti memohon maaf apabila masih terdapat kekurangan dalam penulisan jurnal ini dan terima kasih telah menyempatkan waktunya untuk membaca jurnal ini.

\section{Funding Statement}

The authors did not receive support from any organization for the submitted work and No funding was received to assist with the preparation of this manuscript

\section{Conflict of Interest statement}

Penulis yang namanya tercantum tepat di bawah ini menyatakan bahwa TIDAK memiliki afiliasi atau keterlibatan dengan pihak luar manapun dan tulisan ini murni dari 
sumber yang dicantumkan di daftar pustaka serta tidak mengandung plagarisme dari jurnal artikel manapun. Sumber tulisan telah dicantumkan seluruhnya di daftar pustaka.

\section{REFERENCES}

Alzheimer's Association. (2017). Alzheimer's disease facts and figures. Available online: https://www.alz.org/media/images/2017-facts-andfigures.pdf

Alzheimer's Association. (2018). Stages of alzheimer's disease. Available online: https://www.alz.org/alzheimers$\underline{\text { dementia/stages }}$

Alzheimer's Association. (2021). Treatments for Alzheimer's \& Dementia. Retrieve from: https://www.alzheimers.org.uk/aboutdementia/treatments/drugs

Bahan Ajar I Penyakit Alzheimer. (2013). [(accessed 18 April 2021)]; Retrieve from: https://med.unhas.ac.id/kedokteran/wpcontent/uploads/2016/09/Bahan-Ajar-4_Alzheimer.pdf

Nisa K.M., Lisiswanti R. (2016). Faktor Risiko Demensia Alzheimer. Jurnal Majority, 5(4), 86-90, doi: https://juke.kedokteran.unila.ac.id/index.php/majority/articl e/download/890/798

Pattni, K. A.M. (2013). Beta-Amyloid Sebagai Patogenesis pada Penyakit Alzheimer. Jurnal Medika Udayana, 2(8), 1-11, doi: https://ojs.unud.ac.id/index.php/eum/article/download/6103 $\underline{4594}$

Pedoman Praktik Klinik Diagnosis dan Penatalaksanaan Demensia. (2015). Jakarta: Perhimpunan Dokter Spesialis Saraf Indonesia. Available online: http://www.neurona.web.id/paper/PPK\%20demensia.pdf

Perl, D. (2010). Neuropathology of Alzheimer's Disease. Mount Sinai Journal of Medicine: A Journal of Translational and Personalized Medicine, 77(1), 32-42. doi: https://pubmed.ncbi.nlm.nih.gov/20101720/

Yosenia B. (2018). Penyakit alzheimer. Retrieve from: https://osf.io/ytfzb/download/?format=pdf 